\title{
Microbial indicators of faecal contamination in waters and sediments of beach bathing zones
}

\author{
M.C. Garrido-Pérez*, E. Anfuso, A. Acevedo, J.A. Perales-Vargas-Machuca \\ Department of Chemical Engineering, Food Technologies and Environmental Technologies, \\ Faculty of Marine and Environmental Sciences, University of Cadiz, Pol. Río San Pedro s/n, 11510 Puerto Real, Cadiz, Spain
}

Received 13 June 2006; received in revised form 15 January 2007; accepted 10 September 2007

\begin{abstract}
This study presents the results obtained of the microbial characterization of waters and sediments of 18 coastal bathing zones of the south-western coast of the Iberian Peninsula. To make this characterization, two indicators of faecal contamination have been selected: faecal coliforms (FC) and Clostridium perfringens (CP). The results show that low concentrations of FC and CP in water not necessarily implies that their concentration in sediment and elutriates has to be low as well. The highest concentrations were found in locations close to the mouth of rivers, and in beaches of low energy and hence low water renewal, and high accumulation of fine sediments. The concentrations of FC were lower than those obtained for $\mathrm{CP}$ in most of the sampling locations. Although quality standards for bathing waters do not take the parameter CP into account, it has been demonstrated that it should be a good indicator of faecal contamination.
\end{abstract}

(C) 2007 Elsevier GmbH. All rights reserved.

Keywords: Microbial pollution; Faecal coliforms; Clostridium; Bathing waters; Marine sediments; Elutriate; Cadiz (Spain)

\section{Introduction}

Coastal water pollution by urban wastewater is a fundamental environmental problem on a world scale (Steets and Holden, 2003; Wells, 2003). In the European Union, Directive 76/160/CEE (ECC, 1976) relating to the quality of bathing waters, regulates a total of five microbial indicators that are accepted indicators for sanitary control in bathing waters: total coliforms, faecal coliforms (FC), faecal streptococci, Salmonella and enteroviruses. Due to the difficulty and the cost represented by the analysis of Salmonella and enteroviruses, currently the routine microbial control of

\footnotetext{
*Corresponding author. Tel.: + 34956016423 ; fax: +34956016040

E-mail address: carmen.garrido@uca.es (M.C. Garrido-Pérez).
}

bathing waters is limited to the monitoring of coliforms and streptococci. This is one of the reasons that has led the European Commission to put forward, on various occasions during the last decade, the need to revise and modify the ruling Directive, with the objective of adapting the microbial quality criteria, to current scientific and technological progress (ECC, 2002). On February 2006 was approved the Directive 2006/7/CE concerning the management of bathing water quality and repealing Directive 76/160/EEC (ECC, 2006). One of the main aims of this Directive is to tighten but simplify the health standards for bathing water, limiting microbial control of waters to Escherichia coli, and Enterococcus intestinalis, bacterial groups included within the groups of "faecal coliforms" and "faecal streptococci", respectively. The new indicators selected provide the best correspondence available between 
faecal contamination and the "short-term" health effects in recreational waters.

A significant deficiency in the previously cited normatives is that monitoring of bathing zones is limited to the waters, without taking into account the presence and concentration of microorganisms in the sediments or beds of aquatic systems. In general, very few studies have been published related to microbial quality of marine sediments. In some of these studies, it is concluded that, while the survival rate of microorganisms is slow in waters, in contrast, sediments are reservoirs of a many enteric organisms (Stephenson and Rychert, 1982; Stenstrom and Carlander, 2001; Wheeler et al., 2003; Shibata et al., 2004). This greatly increased rate of survival of these microorganisms in sediments is due to several reasons: the better nutritive conditions of sediment (Davies et al., 1995; Villar et al., 1999); sediment is a compartment that is more protected against the inactivation produced by solar radiation (Sinton et al., 1994; Davies-Colley et al., 1999); and it provides greater protection against depredation by protozoans (Davies and Bavor, 2000).

The genus Clostridium is notable within the group of more resistant microorganisms. Clostridium is a group of anaerobic bacteria whose natural habitat is the soil or animal and human intestines where they live as saprophytes. These microorganisms are characterized by forming endospores that enable them to survive in different habitats, both terrestrial and aquatic, waiting for favourable conditions for their growth. Thanks to these characteristics, they can be considered indicators of remote episodes of anthropogenic contamination, since they remain in a latent state while temperatures remain below $20^{\circ} \mathrm{C}$ or in the presence of oxygen. In the last decade, the importance of this bacterial group in the study and control of coastal waters and sediments has been reflected in numerous papers and protocols (USEPA, 1986; Hill et al., 1996; Edwards et al., 1998; Lipp et al., 2001; Shibata et al., 2004; Skanavis and Yanko, 2001; Hughes and Thompson, 2004; Characklis et al., 2005; Dahlen et al., 2006).

In bathing zones, the continuous movement of the sediment could produce a transference of microorganisms to the water column (Crabill et al., 1999; An et al., 2002; Craig et al., 2004). Therefore, although the "first" and the "new" Directive do not include the microbial control of sediments, it is necessary to conduct studies that evaluate the possibility of including the analysis of sediments in these zones, and other groups of more resistant microorganisms that allow the identification of "long-term" faecal pollution.

In this paper, we present the results obtained from the microbial characterization of the waters, sediments and elutriates sampled from 18 beaches situated over a length of $200 \mathrm{~km}$ of the littoral of the province of Cadiz, in the southwest of the Iberian Peninsula. This characterization has been carried out with two related objectives: (I) to evaluate the possibility of utilizing the bacterial group "Clostridium perfringens" (CP) in the sanitary control of beaches, as a "long-term" microbial indicator of faecal pollution; and (II) to compare the microbial results obtained in samples of water, sediments and elutriates of sediments in bathing zones.

\section{Material and methods}

\section{Description of the sampling zone}

The zone of study is situated in the extreme southwest of Europe, between $5^{\circ}$ and $6^{\circ}$ of longitude west, and between $36^{\circ}$ and $37^{\circ}$ of latitude north, close to the Strait of Gibraltar, at the confluence of the Atlantic Ocean and the Mediterranean Sea. Fig. 1 shows the location of the beaches selected for this study.

The littoral strip sampled has a semidiurnal tidal range, and mean tidal heights between 1.20 and $3.30 \mathrm{~m}$. Most of the beaches are composed of fine-medium grain size sand $\left(D_{50}=250 \mu \mathrm{m}\right)$ consisting of quartz at $85-95 \%$ and calcium carbonate at 5-15\% (Muñoz et al., 2001). The station situated in the inner waters of the Bay of Cadiz (station no. 7) present a variable composition of mud and sand $\left(D_{50}=100-330 \mu \mathrm{m}\right)$ (Forja et al., 2004).

During the period of sampling (5 consecutive days of April-May just before the bathing season), the ambient temperature ranged $20-22^{\circ} \mathrm{C}$ and the sky was clear with practically no cloud.

\section{Sampling strategy}

Sample locations were selected as a single point located in the area of highest bather density of each beach. In each location, water and sediments samples were taken in at low tide, just on the change from ebb to flood flow, and according to the sampling methodology approved in Directive 2006/7/CE (ECC, 2006). First, a sample of the water column was taken at $30 \mathrm{~cm}$ below the surface, to avoid the layer of water directly affected by the ultraviolet radiation of the sun. Water samples were collected in sterile borosilicate bottles. Next, a singlesurface (top $4 \mathrm{~cm}$ ) sediment samples were collected using a small Van Been grab sampler (11) and stored in a sterile bag. Both samples were stored in a cool box (temperature around $4{ }^{\circ} \mathrm{C}$ and darkness), and immediately they were transported to the laboratory for analysis. The time between sampling and analysis was less than $4 \mathrm{~h}$.

\section{Microbial analysis of the samples}

The determination of the microbial indicators in liquid samples was done using the technique of 


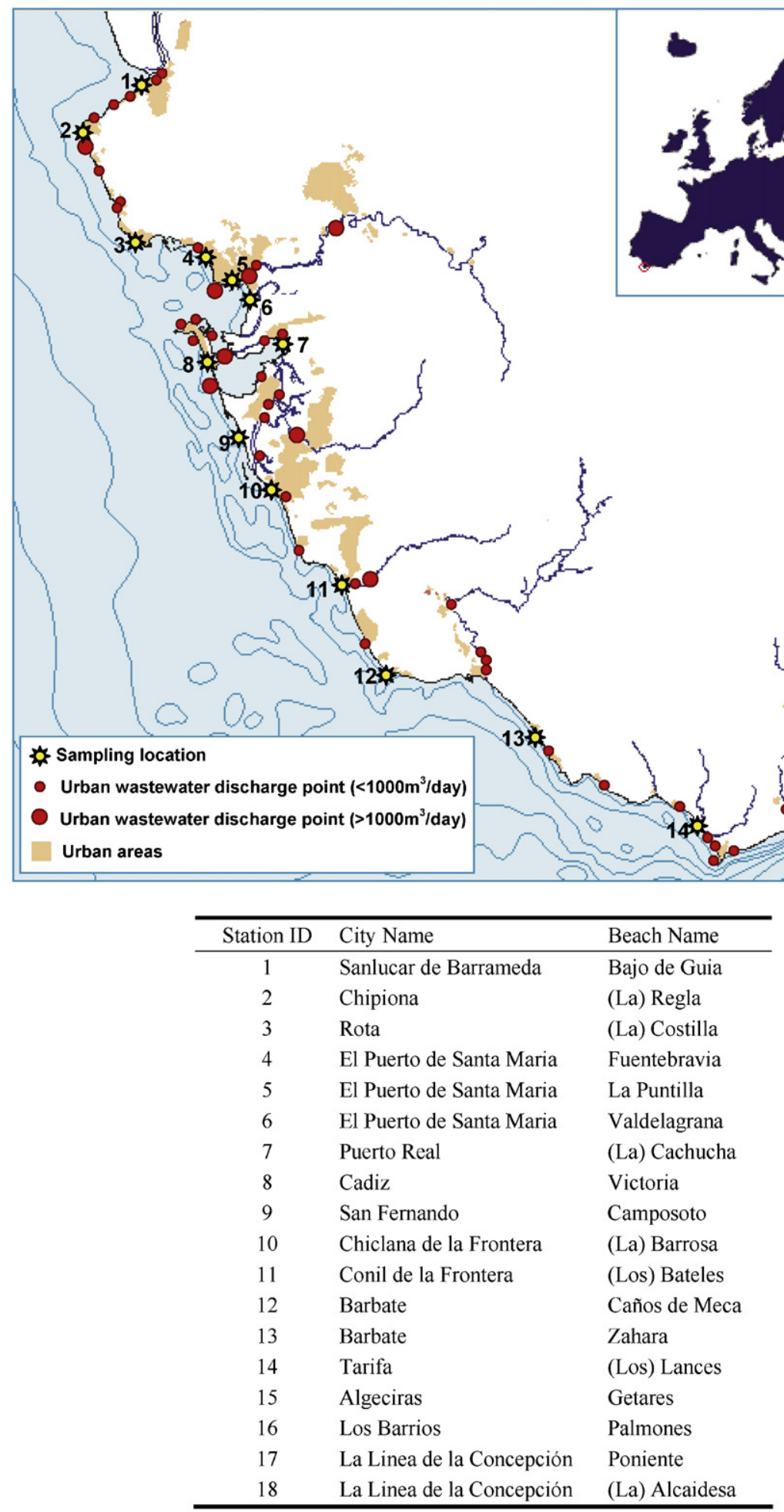

Fig. 1. Locations and codes of sampling bathing zones.

membrane filtration and incubation in a culture medium at an adequate temperature (APHA, 1992). Each sample was analysed in triplicate. The nutritive medium $\mathrm{m}-\mathrm{FC}$ Broth Base (Difco Laboratories) was utilized for the analysis of FC. The incubation temperature was $45 \pm 0.5^{\circ} \mathrm{C}$, and the incubation time was $24 \mathrm{~h}$. Dark blue colonies were counted as FC. CP were enumerated on m-CP Agar Base (Scharlab, S.L.) and incubated anaerobically for $48 \mathrm{~h}$ at $45 \pm 0.5^{\circ} \mathrm{C}$. The anaerobic incubation atmosphere was obtained utilizing a GasPack (Mitsubishi Gas Chemical Company, Inc.) jar and an AnaeroGen ${ }^{\mathrm{TM}}$ (Oxoid Limited) system for the 
generation of anaerobic medium, controlled by a BR-55 (Oxoid Limited) indicator for anaerobiosis. Yellow colonies that turned dark pink to magenta after exposure to ammonium hydroxide fumes were counted as $\mathrm{CP}$.

The most probable number (MPN) was the technique employed for the analysis of the sediment samples (USEPA, 1986). Prior to the seeding, sediment was mixed with buffered water $(\mathrm{pH}=7.2)$ in the proportion 1:1 (weight/volume). Four series of dilutions of the mixture on logarithmic scale with the nutritive medium were prepared: $1 / 1,1 / 10,1 / 100$ and $1 / 1000$ (volume/ volume). The $1 / 1$ dilution is obtained making a doubleconcentrated culture medium. Each dilution was analysed in quintuplicate. For the analysis of FC, the A-1 (Difco Laboratories) medium was utilized. For the analysis of CP, the medium utilized was Lactose Sulfite broth (Scharlab, S.L.). The temperatures, time and conditions of incubation were the same as those described in the microbial analysis of waters. For the identification of positive tubes, a Durhan-type bell was introduced into each tube before proceeding to sterilize the culture medium. Once the period of incubation had elapsed, those tubes that presented gas in the bell, produced by microbial decomposition, were identified as positive. Each sample was analysed in triplicate.

\section{Microbial analysis of elutriates from the sediment}

It is important to know the concentration of microorganisms in the pore water because these could migrate most easily to the water column under turbulent conditions than those attached to the sediment. For this, it is customary to perform procedures of elutriation of the sediments and the subsequent analysis of the aqueous fraction of elutriates (USEPA, 1991). The procedure of elutriation consisted of mixing the sediment with sterilized synthetic seawater (formula from APHA, 1992) in 1:4 (weight/volume) proportion (USEPA/USACE, 1998). The mixture is stirred vigorously for $30 \mathrm{~min}$ with a magnetic stirrer. At $10 \mathrm{~min}$ intervals, the mixture is also stirred manually to ensure complete mixing. After the $30 \mathrm{~min}$ mixing period, the mixture is allowed to settle for $1 \mathrm{~h}$ (USEPA, 1991). The supernatant is then extracted using sterile pipette. The aqueous phase obtained was analysed using the technique of the MPN as described previously.

\section{Expression of the results}

The microbial results obtained have been referred to a volume of $100 \mathrm{~mL}$ in the analyses utilizing the membrane filtration technique, and to a dry weight of $100 \mathrm{~g}$ when the MPN technique was utilized in the analysis of sediment and elutriate. With the objective of being able to compare the number of bacteria obtained in each phase, the specific density of water has been approximated to $1 \mathrm{~g} / \mathrm{mL}$.

\section{Chemical analysis of waters and sediments}

Temperature of water was measured in each location before the sampling strategy using an electronic portable thermometer (Hanna instruments checktemp). Mean water temperature was $17.9 \pm 0.2^{\circ} \mathrm{C}$.

Some complementary analyses were performed on waters and sediments in the laboratory. In waters, the $\mathrm{pH}$ (Crison GLP-21 pHmeter) and the salinity (Crison GLP-32 conductivimeter) of the samples were measured according to the procedures proposed by Grasshoff et al. (1983). In sediments, the dry-weight/wet-weight ratio, necessary for the expression of the microbial results, was determined gravimetrically, drying about $10 \mathrm{~g}$ of sediment in an oven (Selecta S.A. Digitronic) at $105 \pm 1{ }^{\circ} \mathrm{C}$ to constant weight (ASTM, 1996). Also the organic matter content in the sediments was determined by means of calcination of the sample in a Mufla oven (Selecta S.A. Select-Horn) at $550{ }^{\circ} \mathrm{C}$ and subsequent determination of the dry residue and the volatile fraction (APHA, 1992). Water was analysed within $6 \mathrm{~h}$ after sampling time whereas the sediment analysis requires more time, i.e., $24 \mathrm{~h}$ for the wet-dry ratio plus $24 \mathrm{~h}$ for the organic matter determination.

\section{Results and discussion}

Table 1 and Fig. 2 shows the results obtained from the analysis of the microbial indicator $\mathrm{FC}$ in samples of water $(\mathrm{FC}(\mathrm{w}))$, sediment $(\mathrm{FC}(\mathrm{s}))$ and elutriate $(\mathrm{FC}(\mathrm{e}))$ in the bathing zones sampled.

All the concentrations obtained for $\mathrm{FC}(\mathrm{w})$ in this study (single samples) are under the guideline concentration of $200 \mathrm{CFU} / 100 \mathrm{~mL}$ (annual geometrical mean) (Directive 76/160/CEE). They also are under the demanding requirements for coastal bathing waters of excellent quality that are included in the new Directive (Directive 2006/7/EC) of $250 \mathrm{CFU} / 100 \mathrm{~mL}$ (95th percentile evaluation for $E$. coli). With the exception of stations 4 and 5 , which present the highest concentrations of $\mathrm{FC}(\mathrm{w})$, the levels of $\mathrm{FC}(\mathrm{w})$ at the rest of the stations ranged $0-8 \mathrm{CFU} / 100 \mathrm{~mL}$.

The concentrations of $\mathrm{FC}(\mathrm{s})$ and $\mathrm{FC}(\mathrm{e})$ are much higher than in the samples of water, at all stations except station 4. The concentrations of FC(s) ranged 4-12 MPN/100g dry weight, with the exception of stations 7, 16 and 28, where the concentrations are higher $(117,34$ and $28 \mathrm{MPN} / 100 \mathrm{~g}$ dry weight, respectively). 
Table 1. Mean concentration (and standard deviation, $n=3$ ) of faecal coliforms in water, sediment and elutriate of the bathing zones

\begin{tabular}{llllr}
\hline $\begin{array}{l}\text { Station } \\
\text { no. }\end{array}$ & Beach name & $\begin{array}{l}\text { FC(w) } \\
(\mathrm{CFU} /\end{array}$ & $\begin{array}{l}\text { FC(s) } \\
(\mathrm{MPN} /\end{array}$ & $\begin{array}{r}\text { FC(e) } \\
(\mathrm{MPN} /\end{array}$ \\
& & & $\begin{array}{l}100 \mathrm{~g} \text { dry } \\
\text { weight })\end{array}$ & $\begin{array}{r}100 \mathrm{~g} \text { dry } \\
\text { weight })\end{array}$ \\
\hline 1 & Bajo de Guia & $0(0)$ & $28(23)$ & $13(2)$ \\
2 & La Regla & $0(0)$ & $10(1)$ & $6(1)$ \\
3 & La Costilla & $3(3)$ & $10(6)$ & $12(2)$ \\
4 & Fuentebravia & $17(8)$ & $10(1)$ & $7(1)$ \\
5 & La Puntilla & $22(3)$ & $4(1)$ & $6(1)$ \\
6 & Valdelagrana & $8(8)$ & $10(1)$ & $25(2)$ \\
7 & La Cachucha & $2(3)$ & $117(2)$ & $60(2)$ \\
8 & Victoria & $2(3)$ & $12(1)$ & $6(1)$ \\
9 & Camposoto & $0(0)$ & $10(1)$ & $5(1)$ \\
10 & La Barrosa & $0(0)$ & $10(1)$ & $5(1)$ \\
11 & Los Bateles & $0(0)$ & $10(1)$ & $5(1)$ \\
12 & Caños de & $0(0)$ & $10(1)$ & $6(1)$ \\
& Meca & & & \\
13 & Zahara & $3(6)$ & $4(6)$ & $7(1)$ \\
14 & Los Lances & $3(6)$ & $10(1)$ & $6(1)$ \\
15 & Getares & $0(0)$ & $10(6)$ & $6(1)$ \\
16 & Palmones & $5(5)$ & $34(10)$ & $23(4)$ \\
17 & Poniente & $0(0)$ & $4(1)$ & $6(1)$ \\
18 & La Alcaidesa & $2(3)$ & $14(95)$ & $75(10)$ \\
\hline & & & &
\end{tabular}

Table 2 presents the results obtained from the analysis of $\mathrm{CP}$ in samples of water $(\mathrm{CP}(\mathrm{w}))$, sediment $(\mathrm{CP}(\mathrm{s}))$ and elutriate $(\mathrm{CP}(\mathrm{e}))$.

The concentrations of $\mathrm{CP}$ in the three media are found to be clearly higher than those obtained for the parameter FC (Table 1). This difference is especially striking in the case of the samples of sediment, where the concentrations of $\mathrm{CP}$ are between one and two orders of magnitude greater than those of FC. These differences may be due to the greater resistance of the $\mathrm{CP}$ spores in marine environments, compared with the FC (Skanavis and Yanko, 2001).

In a work done in Hawaiian streams, Fujioka and Shizumura (1985) suggested that concentrations of CP higher than $50 \mathrm{CFU} / 100 \mathrm{~mL}$ are indicative of human faecal contamination in water. Other authors (Lipp et al., 2001) used this criterion to determine the faecal origin of CP in coastal zones. In accordance with this criterion, of the 18 bathing zones sampled, four would be considered to be affected by faecal contamination in the water column, while 16 would be so considered with respect to the sediment.

In Table 3, the complementary chemical results analysed in the bathing waters and sediments sampled are shown. Table 4 shows the Pearson Correlation matrix among all the chemical and microbial variables determined in this study.
Faecal coliform

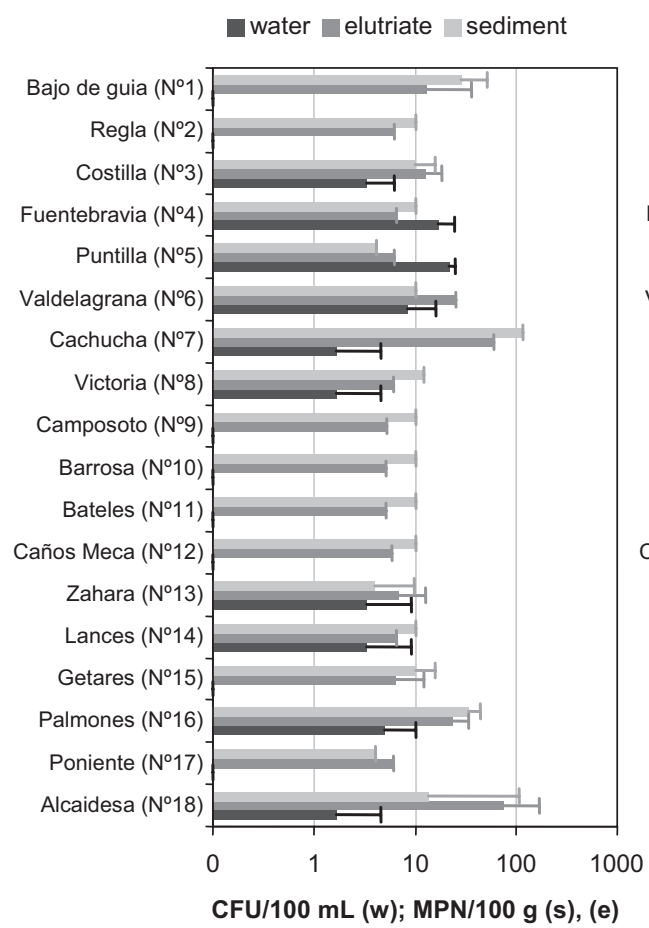

\section{Clostridium perfringens}

nater elutriate sediment

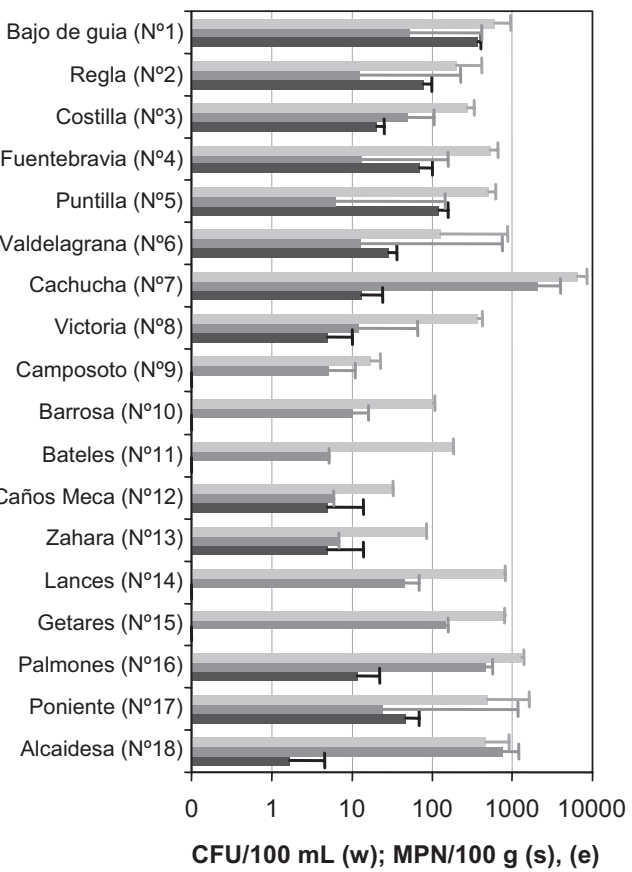

Fig. 2. Mean density ( $\perp$ Standard Deviation) of Faecal coliform and Clostridium perfringens in water (w), sediment (s) and elutriate (e) of 18 bathing zones. 
Table 2. Mean concentration (and standard deviation, $n=3$ ) of Clostridium perfringens in water, sediment and elutriate of the bathing zones

\begin{tabular}{|c|c|c|c|c|}
\hline $\begin{array}{l}\text { Station } \\
\text { no. }\end{array}$ & Beach name & $\begin{array}{l}\mathrm{CP}(\mathrm{w}) \\
(\mathrm{CFU} / \\
100 \mathrm{~mL})\end{array}$ & $\begin{array}{l}\mathrm{CP}(\mathrm{s}) \\
(\mathrm{MPN} / \\
100 \mathrm{~g} \text { dry } \\
\text { weight) }\end{array}$ & $\begin{array}{l}\text { CP (e) } \\
\text { (MPN/ } \\
100 \mathrm{~g} \text { dry } \\
\text { weight) }\end{array}$ \\
\hline 1 & Bajo de Guia & $363(35)$ & $614(354)$ & $51(3)$ \\
\hline 2 & (La) Regla & 77 (20) & 197 (214) & $12(6)$ \\
\hline 3 & (La) Costilla & $20(5)$ & $274(55)$ & $50(23)$ \\
\hline 4 & Fuentebravia & $70(30)$ & $522(143)$ & $13(7)$ \\
\hline 5 & (La) Puntilla & $122(33)$ & 495 (137) & $6(2)$ \\
\hline 6 & Valdelagrana & $28(8)$ & $126(750)$ & $13(2)$ \\
\hline 7 & (La) Cachucha & $13(10)$ & 6596 (1939) & $2061(512)$ \\
\hline 8 & Victoria & $5(5)$ & $367(53)$ & $12(3)$ \\
\hline 9 & Camposoto & $0(0)$ & $17(6)$ & $5(2)$ \\
\hline 10 & (La) Barrosa & $0(0)$ & $102(6)$ & $10(1)$ \\
\hline 11 & (Los) Bateles & $0(0)$ & $180(5)$ & $5(2)$ \\
\hline 12 & Caños de Meca & $5(9)$ & $32(3)$ & $6(4)$ \\
\hline 13 & Zahara & $5(9)$ & $84(4)$ & $7(1)$ \\
\hline 14 & (Los) Lances & $0(0)$ & 807 (23) & 45 (11) \\
\hline 15 & Getares & $0(0)$ & 805 (10) & $148(22)$ \\
\hline 16 & Palmones & $12(10)$ & $1315(95)$ & $467(31)$ \\
\hline 17 & Poniente & $47(21)$ & 485 (1161) & 24 (22) \\
\hline 18 & (La) Alcaidesa & $2(3)$ & 464 (445) & 754 (117) \\
\hline
\end{tabular}

Table 3. Complementary chemical analysis of the samples

\begin{tabular}{lllll}
\hline $\begin{array}{l}\text { Station } \\
\text { no. }\end{array}$ & Beach name & $\begin{array}{l}\mathrm{pH} \\
(\mathrm{w})\end{array}$ & $\begin{array}{l}\text { Salinity } \\
(\mathrm{w})\end{array}$ & $\begin{array}{l}\text { \% Organic } \\
\text { matter }(\mathrm{s})\end{array}$ \\
\hline 1 & Bajo de Guia & 8.01 & 29.2 & 0.75 \\
2 & (La) Regla & 8.19 & 36.0 & 0.92 \\
3 & (La) Costilla & 8.30 & 37.8 & 1.20 \\
4 & Fuentebravia & 8.21 & 38.1 & 1.34 \\
5 & (La) Puntilla & 8.26 & 38.0 & 1.26 \\
6 & Valdelagrana & 8.31 & 38.6 & 0.83 \\
7 & (La) Cachucha & 8.68 & 39.4 & 2.96 \\
8 & Victoria & 8.14 & 39.0 & 0.97 \\
9 & Camposoto & 8.05 & 38.0 & 1.01 \\
10 & (La) Barrosa & 8.05 & 38.1 & 1.13 \\
11 & (Los) Bateles & 8.04 & 38.0 & 0.89 \\
12 & Caños de Meca & 8.15 & 37.7 & 1.10 \\
13 & Zahara & 8.12 & 36.8 & 1.11 \\
14 & (Los) Lances & 8.25 & 41.0 & 1.06 \\
15 & Getares & 8.26 & 40.5 & 2.34 \\
16 & Palmones & 8.16 & 37.6 & 0.72 \\
17 & Poniente & 8.13 & 38.4 & 0.64 \\
18 & (La) Alcaidesa & 8.26 & 37.9 & 0.54 \\
& & & &
\end{tabular}

The lack of correlation between the $\mathrm{FC}(\mathrm{w})$ and $\mathrm{FC}(\mathrm{s})$ or FC(e) indicates that the absence of FC in the water column does not necessarily imply its absence in the sediment. The sediments are usually reservoirs of the contamination that reaches the coastal waters. The difference in the concentration of microorganisms measured between water and sediment as shown by the results corroborates with the results obtained by other authors for bathing zones (Crabill et al., 1999; An et al., 2002; Wheeler et al., 2003; Shibata et al., 2004). In the water column, sunlight is one of the factors that has most influence on the disappearance of microorganisms of enteric origin. Deposition in the sediments provides these microorganisms protection from the ultraviol et radiation of the sun (Wheeler et al., 2003).

Table 4 shows a significant correlation between the concentrations of FC(s) and FC(e). In a bathing zone, where the depth of the water column does not exceed $1.5-2 \mathrm{~m}$ on average, the sediment is in continuous movement caused by the littoral currents, the entry and breaking of the waves on the beach, and the recreational activities of the bathers. Given that the procedure of elutriation simulates the natural agitation of the surface layers of the sediment with the water, this correlation indicates that a part of the FC present in the sediment migrates to the water column.

The average percentage of FC present in the sediment that passed to the aqueous phase following the process of elutriation was $56 \%(\mathrm{SD}=8, n=12)$. Those stations where the samples of elutriate presented FC concentrations higher than those of the sediment have not been considered.

No correlation has been obtained between the concentrations of $\mathrm{CP}$ in water and those in sediment or elutriate. There is a clear correlation between CP in sediment and elutriate. This latter result has the same implications as those presented in the case of the FC: that it is possible for $\mathrm{CP}$ to be transferred from the sediment to the water column in turbulent conditions. Despite the mobility of the CP observed, this is found to be much lower than that of the FC. The average percentage of $\mathrm{CP}$ in the elutriate compared with that originally present in the sediment at the various sampling stations was $12.63 \%(\mathrm{SD}=10.82, n=17)$.

Considering the sampling period was realized in a dry period (no rainfall occurred), the strong correlation existing between $\mathrm{FC}(\mathrm{s})$ and $\mathrm{CP}(\mathrm{s})$ could indicate that the main $\mathrm{CP}(\mathrm{s})$ source is human faecal pollution from domestic wastewater in this coastal area. Other possible sources such as runoff or re-growth in sediments could be present but not in important percentages with respect to the pollution charge of bacteria in this coastal area where the disinfection processes of domestic wastewater are deficient.

Only in the water column it has been observed a significant negative correlation between chemical and microbial indicators; this is between $\mathrm{CP}(\mathrm{w})$ and salinity. It indicates that the bathing waters influenced by continental waters are those that are at greater risk of presenting microbial contamination in the water column by CP. Table 4 confirms this interaction, since the stations situated at the mouths of two important rivers 
Table 4. Matrix of Pearson correlations of the variables analysed in bathing zones

\begin{tabular}{|c|c|c|c|c|c|c|c|c|c|}
\hline & $\mathrm{pH}(\mathrm{w})$ & Salinity (w) & Organic matter (s) & $\mathrm{FC}(\mathrm{w})$ & $\mathrm{FC}(\mathrm{s})$ & $\mathrm{FC}(\mathrm{e})$ & $\mathrm{CP}(\mathrm{w})$ & $\mathrm{CP}(\mathrm{s})$ & $\mathrm{CP}(\mathrm{e})$ \\
\hline $\mathrm{pH}(\mathrm{w})$ & 1.00 & & & & & & & & \\
\hline Salinity (w) & 0.43 & 1.00 & & & & & & & \\
\hline Organic matter (s) & 0.72 & 0.38 & 1.00 & & & & & & \\
\hline $\mathrm{FC}(\mathrm{w})$ & 0.22 & 0.11 & 0.05 & 1.00 & & & & & \\
\hline $\mathrm{FC}(\mathrm{s})$ & 0.72 & 0.02 & 0.67 & -0.12 & 1.00 & & & & \\
\hline $\mathrm{FC}(\mathrm{e})$ & 0.61 & 0.06 & 0.19 & -0.05 & 0.60 & 1.00 & & & \\
\hline $\mathrm{CP}(\mathrm{w})$ & -0.24 & -0.87 & -0.19 & 0.15 & 0.03 & -0.10 & 1.00 & & \\
\hline $\mathrm{CP}(\mathrm{s})$ & 0.80 & 0.17 & 0.76 & -0.03 & 0.97 & 0.57 & -0.05 & 1.00 & \\
\hline $\mathrm{CP}(\mathrm{e})$ & 0.79 & 0.17 & 0.63 & -0.09 & 0.93 & 0.80 & -0.13 & 0.94 & 1.00 \\
\hline
\end{tabular}

Correlations in italics are significant at $p<0.05$.

in the study area (stations 1 and 5) are the ones that present higher concentrations of $\mathrm{CP}(\mathrm{w})$, presumably due to the role that these rivers play as sources of contamination to the sea.

A large number of significant interactions between chemical and microbial indicators of the sediment have been determined. The positive correlations obtained between $\mathrm{FC}(\mathrm{s})$ and $\mathrm{CP}(\mathrm{s})$ and the content in organic matter are especially notable. The stations influenced by the mouths of rivers and the stations where the sediments have a greater content in organic matter, normally sediments of fine granulometry, are those that present the highest concentrations of microorganisms (Tables 1 and 2). The most serious microbial contamination by $\mathrm{FC}(\mathrm{s})$ and $\mathrm{CP}(\mathrm{s})$ and by organic matter corresponds to station 7 situated on a beach of the interior of the Bay of Cadiz, a beach with very fine sediment, subject to low wave action, and influenced by several wastewater discharge points and contaminated runoff. These characteristics could promote processes of accumulation, re-growth and/or survival of microorganisms in the sediment as several authors had shown in coastal areas (Howell et al., 1996; Crabill et al., 1999; Wheeler et al., 2003; Sanders et al., 2005; Evanson and Ambrose, 2006; Lee et al., 2006).

\section{Conclusions}

The principal results drawn from this study are the following:

(I) The absence of FC in bathing waters does not indicate that faecal contamination events have not taken place. The joint analysis of other types of more resistant microbial indicators such as CP provides a useful complementary information when classifying bathing zones as not influenced, in either the short or long term, by domestic wastewater that may represent a risk for the health of sea bathers and of others pursuing recreational activities in these waters.

(II) At present, the sanitary control of bathing waters only involves the microbial characterization of the waters themselves. The microbial results obtained in this study indicate that the absence of indicators of faecal contamination in the waters is not conclusive for stating that the sanitary quality of the bathing waters is guaranteed. Elutriation procedure simulates the turbulence that could occur in the sediments of bathing zones and recreational activities. Migration of FC and CP could takes place from the sediment to the water column. For these reasons it is recommended that microbial analysis of the sediment, both its solid phase and the pore water, should be included in the diagnosis of the microbial quality of bathing waters.

\section{References}

American Public Health Association (APHA), 1992. Standard Methods for the Examination of Water and Wastewater, 18th ed. APHA, Washington, DC.

American Society for Testing and Materials (ASTM), 1996. Standard guide for collection, storage, characterization, and manipulation of sediments for toxicological testing. ASTM E 1391-94. Annual Book of ASTM Standards, vol. 11.05, pp. 805-825.

An, Y.J., Kampbell, D.H., Breidenbach, G.P., 2002. Escherichia coli and total coliforms in water and sediments at lake marinas. Environ. Pollut. 120, 771-778.

Characklis, G.W., Dilts, M.J., Simmons III, O., Likirdopulus, C.A., Krometis, L.A.H., Sobsey, M.D., 2005. Microbial partitioning to settleable particles in stormwater. Water Res. 39, 1773-1782.

Crabill, C., Donald, R., Snelling, J., Foust, R., Southam, G., 1999. The impact of sediment faecal coliform reservoirs on seasonal water quality in Oak Creek, Arizona. Water Res. 33 (9), 2163-2171.

Craig, D., Fallowfield, H., Cromar, N., 2004. Use of macrocosms to determine persistence of Escherichia coli in 
recreational coastal water and sediment and validation with in situ measurements. J. Appl. Microbiol. 96, 922-930.

Dahlen, D., Hunt, C., Emsbo-Mattingly, S., Keay, K., 2006. Are toxic contaminants accumulating in Massachusetts coastal sediments following startup of the Massachussetts Bay outfall: a comprehensive comparison of baseline and post-diversion periods. Mar. Pollut. Bull. 52, 1372-1388.

Davies, C.M., Bavor, I.I.J., 2000. The fate of storm water associated bacteria in constructed wetland and water pollution control pond system. J. Appl. Microbiol. 89 (2), 349-360.

Davies, C.M., Long, J.A.H., Donald, M., Ashbolt, N.J., 1995. Survival of faecal microorganisms in marine and freshwater sediments. Appl. Environ. Microbiol. 61 (5), 1888-1896.

Davies-Colley, R.J., Donnison, A.M., Speed, D.J., Ross, C.M., Nagels, J.W., 1999. Inactivation of faecal indicator microorganisms in waste stabilisation ponds: interaction of environmental factors with sunlight. Water Res. 33 (5), 1220-1230.

Edwards, D.D., Mc Feters, G.A., Venkatesan, M.I., 1998. Distribution of Clostridium perfringens and faecal sterols in a benthic coastal marine environmental influenced by the sewage outfall from McMurdo Station, Antarctica. Appl. Environ. Microbiol. 64, 2596-2600.

European Community Comission (ECC), 1976. Council Directive $76 / 160 / C E C$, of 8 of December of 1975, concerning the quality of bathing waters. Offic. J. L 31, 1-7.

European Community Comission (ECC), 2002. Proposal of Council Directive concerning the quality of bathing waters: COM 2002/0254, 581 final.

European Community Comission (ECC), 2006. Council Directive 2006/7/EC, of 15 February 2006, concerning the management of bathing water quality and repealing Directive 76/160/EEC. Offic. J. L 64, 37-51.

Evanson, M., Ambrose, F., 2006. Sources and growth dynamics of fecal indicator bacteria in a coastal wetland system and potential impacts to adjacent waters. Water Res. 40, 475-486.

Forja, J., Ortega, T., Del Valls, T.A., Gomez-Parra, A., 2004. Benthic fluxes of inorganic carbon in shallow coastal ecosystems of the Iberian Peninsula. Mar. Chem. 85, 141-156.

Fujioka, R.S., Shizumura, L.K., 1985. Clostridium perfringens, a reliable indicator of stream water quality. J. Water Pollut. Control Fed. 57, 982-986.

Grasshoff, K., Ehrhard, M., Kremlings, K., 1983. Methods of Seawater Analysis, second ed. Verlag Chemie, Weinheim.

Hill, R.T., Straube, W.L., Palmisano, A.C., Gibson, S.L., Colwell, R.R., 1996. Distribution of sewage indicated by Clostridium perfringens at a deep-water disposal site after cessation of sewage disposal. Appl. Environ. Microbiol. 62, 1741-1746.

Howell, J.M., Coyne, M.S., Cornelius, P.L., 1996. Effect of sediment particle size and temperature on fecal bacteria mortality rates and the fecal coliform/fecal streptococci ratio. J. Environ. Qual. 25, 1216-1220.

Hughes, K.A., Thompson, A., 2004. Distribution of sewage pollution around a maritime Antarctic research station indicated by faecal coliforms, Clostridium prefringens and faecal sterol markers. Environ. Pollut. 127, 315-321.
Lee, C.M., Lin, T.Y., Lin, Ch., Kohbodi, G.A., Bhatt, A., Lee, R., Jay, J.A., 2006. Persistence of fecal indicator bacteria in Santa Monica Bay beach sediments. Water Res. 40, 2593-2602.

Lipp, E.K., Farrah, S.A., Rose, J.B., 2001. Assessment and impact of microbial faecal pollution and human enteric pathogens in a coastal community. Mar. Pollut. Bull. 42 (4), 286-293.

Muñoz, J.J., Lopez de San Roman, B., Gutierrez-Mas, J.M., Moreno, L., Cuena, G.J., 2001. Cost of beach maintenance in the Gulf of Cadiz SW Spain. Coastal Eng. 42, 143-153.

Sanders, B.F., Arega, F., Sutula, M., 2005. Modeling the dryweather tidal cycling of fecal indicator bacteria in surface waters of an intertidal wetland. Water Res. 39, 3394-3408.

Shibata, T., Solo-Gabriele, H.M., Fleming, L.E., Elmir, S., 2004. Monitoring marine recreational water quality using multiple microbial indicators in an urban tropical environment. Water Res. 38, 3119-3131.

Sinton, L.W., Davies-Colley, R.J., Bell, R.G., 1994. Inactivation of enterococci and faecal coliforms from sewage and meatwork effluents in seawater chambers. Appl. Environ. Microbiol. 60 (6), 2040-2048.

Skanavis, C., Yanko, W.A., 2001. Clostridium prefringens as a potential indicator for the presence of sewage solids in marine sediments. Mar. Pollut. Bull. 42 (1), 31-35.

Steets, B.M., Holden, P.A., 2003. A mechanistic model of runoff-associated fecal coliform fate and transport through a coastal lagoon. Water Res. 37, 589-608.

Stenstrom, T.A., Carlander, A., 2001. Occurrence and die off of indicator organism in the sediment in two constructed wetlands. Water Sci. Technol. 44 (11-12), 223-230.

Stephenson, G.R., Rychert, R.C., 1982. Bottom sediment a reservoir of Escherichia coli in rangeland streams. J. Range Manage. 35 (1), 119-123.

United States Environmental Protection Agency (USEPA), 1986. Recommended protocols for microbiological studies in Puget Sound. Puget Sound Estuary Program, Puget Sound Monitoring Program. USEPA, Region 10. Office of Puget Sound, Settle, WA.

United States Environmental Protection Agency (USEPA), 1991. Evaluation of Dredged Material Proposed for Ocean Disposal, Testing Manual. Office of Water (4504F), EPA 503/8-91/001.

United States Environmental Protection Agency (USEPA), United States Army Corps of Engineers (USACE), 1998. Evaluation of Dredged Material Proposed for Discharge in Waters of the US Washington, DC - testing manual, EPA823-B-98-004.

Villar, C., De Cabo, L., Vaithiyanathan, P., Bonetto, C., 1999. Pore water $\mathrm{N}$ and $\mathrm{P}$ concentration in a floodplain marsh of the Lower Parana River. Hydrobiology 392 (1), 65-71.

Wells, P.G., 2003. State of the marine environment reports - a need to evaluate their role in marine environmental protection and conservation. Mar. Pollut. Bull. 46, 1219-1223.

Wheeler, E.A., Burke, J., Spain, A., 2003. Faecal indicator bacteria are abundant in wet sand at freshwater beaches. Water Res. 37, 3878-3983. 